\title{
Formulation of ${ }^{18}$ F-FDG: $\mathrm{pH}$ Adjustment of Buffered Solution
}

\author{
Teresa Martinez ${ }^{1}$ and Luis Leiva ${ }^{2}$ \\ ${ }^{1}$ Unidad de Radiofarmacia, Hospital General Universitario Santa Lucía, Cartagena, Murcia, Spain; and ${ }^{2}$ Unidad Centralizada de \\ Radiofarmacia Molypharma, Galdácano, Vizcaya, Spain
}

\begin{abstract}
The steam-sterilized ${ }^{18} \mathrm{~F}-\mathrm{FDG}$ of our laboratory frequently has a $\mathrm{pH}$ of around 6.5. To avoid decomposition, we studied the possibility of adjusting the $\mathrm{pH}$ by adding a pharmaceutical compound but without modifying the usual production sequence and reagents. Methods: Citric acid in 4 concentrations $(0.01$, $0.03,0.05$, and $0.06 \mathrm{M}$ ) was added to routine batches of ${ }^{18} \mathrm{~F}$ FDG. Established pharmacopeia quality controls at 0 and $12 \mathrm{~h}$ after synthesis were run, and the dilution effect was checked. Results: A $0.06 \mathrm{M}$ concentration of $1: 15 \mathrm{v} / \mathrm{v}$ citric acid brought about a $\mathrm{pH}$ range of 5.46-5.68; did not change significantly after $1 / 10$ dilution; and did not interfere with quality control. The results of quality control $12 \mathrm{~h}$ after dispensing were in the desired range. Conclusion: A $0.06 \mathrm{M}$ concentration of $1: 15 \mathrm{v} / \mathrm{v}$ citric acid modifies $\mathrm{pH}$ in a buffered ${ }^{18} \mathrm{~F}-\mathrm{FDG}$ solution without the need to change the synthesizer protocol or reagent composition. This new formulation allows $\mathrm{pH}$ adjustment; is an easy, reliable, and safe method with no technical difficulties; and does not interfere with the quality of the radiopharmaceutical.
\end{abstract}

Key Words: buffer; ${ }^{18} \mathrm{~F}-\mathrm{FDG}$; citric acid; $\mathrm{pH}$

J Nucl Med Technol 2012; 40:48-49

DOI: 10.2967/jnmt.111.092825

$\mathbf{T}$ emperature, $\mathrm{pH}$, and specific volume play an important role in ${ }^{18}$ F-FDG stability. Impurities from epimerization and hydrolysis have been observed at a more alkaline $\mathrm{pH}$ (1). The rate of decomposition due to steam sterilization is diminished in an acidic environment, and radiolysis of high-activity ${ }^{18} \mathrm{~F}-\mathrm{FDG}$ solutions is significantly lower at pH 5.5 than at a neutral pH. pH 5.5 appears to be optimal and gives ${ }^{18} \mathrm{~F}-\mathrm{FDG}$ of high radiochemical purity $(\sim 99 \%)$ (2).

The steam-sterilized citrate-buffered ${ }^{18} \mathrm{~F}-\mathrm{FDG}$ solution synthesized in a commercial module in our laboratory repeatedly shows a $\mathrm{pH}$ higher than 6.5 , with the presence of undesirable ${ }^{18} \mathrm{~F}$-fluorodeoxymannose. We proposed to ad-

\footnotetext{
Received May 10, 2011; revision accepted Sep. 15, 2011.

For correspondence or reprints contact: Teresa Martínez, Unidad de Radiofarmacia, Hospital General Universitario Santa Lucia, C/Mezquita, s/n, Paraje Los Arcos, 30202, Santa Lucía, Cartagena, Murcia, Spain.

E-mail: tmmtnez@gmail.com; mteresa.martinez5@carm.es Published online Jan. 25, 2012.

COPYRIGHT @ 2012 by the Society of Nuclear Medicine, Inc.
}

just the $\mathrm{pH}$ closer to 5.5 by adding citric acid to ${ }^{18} \mathrm{~F}$-FDG before sterilization by heat, without modifying the synthesis sequence and reagent composition.

Citric acid monohydrate (reagent specification as per the European Pharmacopoeia; Merck) was chosen because of the reagent composition of the TRACERlab MX synthesizer (GE Medical Systems) (buffer vial contains disodium hydrogen citrate-1,5-hydrate and trisodium citrate-2-hydrate; ABX Advanced Biochemical Compounds), its acidity and dissociation constants $\left(\mathrm{pH} 2.2\right.$ in $0.1 \mathrm{~N}$ solution; $\mathrm{p} K_{\mathrm{a}} 1=$ $3.09, \mathrm{p} K_{\mathrm{a}} 2=4.75(3)$, where $\mathrm{p} K_{\mathrm{a}}$ is the negative logarithm of the acid dissociation constant), and its recognition as an excipient in pharmacopeias $(4,5)$.

\section{MATERIALS AND METHODS}

Citric acid monohydrate in $0.01,0.03,0.05$, and $0.06 \mathrm{M}$ solution was added in various ratios to three ${ }^{18} \mathrm{~F}$-FDG solutions with $\mathrm{pH}$ higher than $6.5(1: 1,1: 15,1: 30$, and 1:60 citric acid: $\left.{ }^{18} \mathrm{~F}-\mathrm{FDG}[\mathrm{v} / \mathrm{v}][30.00-0.16 \mathrm{mM}]\right)$. $\mathrm{pH}$ was tested in all cases (pH meter 3520 [Jenway], with a glass electrode).

TABLE 1

$\mathrm{pH}$ of ${ }^{18} \mathrm{~F}-\mathrm{FDG}$ with Citric Acid Added

\begin{tabular}{ccccc}
\hline \multirow{2}{*}{$\begin{array}{c}\text { Initial citric acid } \\
\text { concentration } \\
(\mathrm{M})\end{array}$} & $\begin{array}{c}\text { Ratio of citric } \\
\text { acid to }\end{array}$ & \multicolumn{3}{c}{$\begin{array}{c}\mathrm{pH} \text { of } \\
\text { 18F-FDG }\end{array}$} \\
\cline { 3 - 5 }${ }^{18} \mathrm{~F}-\mathrm{FDG}(\mathrm{v} / \mathrm{v})$ & Batch 1 & Batch 2 & Batch 3 \\
\hline 0.01 & 0 & 6.58 & 6.59 & 6.61 \\
& $1: 1$ & 4.98 & 4.94 & 4.94 \\
& $1: 15$ & 6.27 & 6.25 & 6.26 \\
0.03 & $1: 30$ & 6.27 & 6.28 & 6.24 \\
& $1: 60$ & 6.29 & 6.28 & 6.29 \\
& $1: 1$ & 3.91 & 3.90 & 3.91 \\
0.05 & $1: 15$ & 5.84 & 5.83 & 5.84 \\
& $1: 30$ & 5.89 & 5.90 & 5.88 \\
& $1: 60$ & 5.88 & 5.87 & 5.87 \\
0.06 & $1: 1$ & 3.54 & 3.49 & 3.47 \\
& $1: 15$ & 5.70 & 5.71 & 5.66 \\
& $1: 30$ & 5.65 & 5.65 & 5.65 \\
& $1: 60$ & 5.62 & 5.65 & 5.65 \\
& $1: 1$ & 3.36 & 3.33 & 3.32 \\
& $1: 15$ & 5.5 & 5.51 & 5.52 \\
& $1: 30$ & 5.58 & 5.57 & 5.58 \\
& $1: 60$ & 5.57 & 5.57 & 5.58 \\
\hline
\end{tabular}


TABLE 2

Data of Formulation Tested in ${ }^{18}$ F-FDG Routine Production

\begin{tabular}{|c|c|c|c|}
\hline \multirow[b]{2}{*}{ Parameter } & \multicolumn{3}{|c|}{$1: 15 \mathrm{v} / \mathrm{v}$ citric acid: ${ }^{18} \mathrm{~F}-\mathrm{FDG}$} \\
\hline & $0.06 \mathrm{M}$ & $0.05 \mathrm{M}$ & $0.03 \mathrm{M}$ \\
\hline Number of batches studied & 10 & 10 & 10 \\
\hline Radioactivity concentration of batches studied $(\mathrm{MBq} / \mathrm{mL})$ & $2,600-4,000$ & $2,600-4,000$ & $2,600-4,000$ \\
\hline $\mathrm{pH}$ range & $5.46-5.68$ & $5.51-6.22$ & $5.68-6.52$ \\
\hline${ }^{18} \mathrm{~F}$-fluorodeoxymannose (median $\pm \mathrm{SD}$ ) & $0.83 \% \pm 0.73 \%$ & $1.78 \% \pm 0.81 \%$ & $1.94 \% \pm 0.81 \%$ \\
\hline Pharmacopeia quality control & Passed & Passed & Passed \\
\hline $\mathrm{pH}$ and radiochemical purity $12 \mathrm{~h}$ after synthesis & Passed & Passed & Passed \\
\hline
\end{tabular}

The use of $1: 15 \mathrm{v} / \mathrm{v}$ citric acid in $0.03 \mathrm{M}(n=10), 0.05 \mathrm{M}$ $(n=10)$, and $0.06 \mathrm{M}(n=10)$ concentrations was studied in 30 batches of ${ }^{18}$ F-FDG $(2,600-4,000 \mathrm{MBq} / \mathrm{mL})$, and pharmacopeia quality controls were run in all cases.

\section{RESULTS}

${ }^{18} \mathrm{~F}-\mathrm{FDG}$ at $1: 1 \mathrm{v} / \mathrm{v}$ reached a $\mathrm{pH}$ lower than $5.5(\mathrm{pH} 4 \pm$ 1) for the 4 chosen concentrations. A $0.01 \mathrm{M}$ concentration of 1:15, 1:30, and 1:60 v/v citric acid did not decrease $\mathrm{pH}$ enough (6.20 \pm 0.10$)$. However, 0.03, 0.05, and $0.06 \mathrm{M}$ concentrations of $1: 15 \mathrm{v} / \mathrm{v}$ citric acid brought about suitable $\mathrm{pH}$ values, as indicated in Table 1.

In routine batch production, the addition of a $0.06 \mathrm{M}$ concentration of $1: 15 \mathrm{v} / \mathrm{v}$ citric acid produced a $\mathrm{pH}$ range of $5.46-5.68$, a $0.05 \mathrm{M}$ concentration produced a $\mathrm{pH}$ range of 5.51-6.22, and a $0.03 \mathrm{M}$ concentration produced a $\mathrm{pH}$ range of 5.68-6.52. Pharmacopeia quality controls had results similar to those for ${ }^{18} \mathrm{FDG}$ with no citric acid added (Table 2).

Dilution with physiologic saline to at least $1 / 10$ was well tolerated.

$\mathrm{pH},{ }^{18} \mathrm{~F}-\mathrm{FDG}$, and free ${ }^{18} \mathrm{~F}$-fluoride met pharmacopeia requirements $12 \mathrm{~h}$ after dispensing.

\section{DISCUSSION}

Formulation with a $0.06 \mathrm{M}$ concentration of $1: 15 \mathrm{v} / \mathrm{v}$ citric acid produced $\mathrm{pH}$ values closer to 5.5 in batches of ${ }^{18} \mathrm{~F}$-FDG ranging from 2,600 to $4,000 \mathrm{MBq} / \mathrm{mL}$. Dilution with physiologic saline to at least $1 / 10$ was well tolerated, but batches of higher activity should be tested.

To avoid degradation, the use of some acidic species is common in the formulation $(2,6,7)$, but differences in formulation can have a profound effect on the radiochemical purity of ${ }^{18} \mathrm{~F}-\mathrm{FDG}(8)$. In our case, pharmacopeia quality controls showed results similar to those of ${ }^{18} \mathrm{~F}-\mathrm{FDG}$ with no citric acid added. Therefore, the substance did not interfere in quality tests (endotoxin test included; no inhibition was detected). The new formulation retained radiochemical purity for at least $12 \mathrm{~h}$.

\section{CONCLUSION}

This new formulation can be considered acceptable for routine production. It is an easy, reliable, and safe way to adjust the $\mathrm{pH}$ of ${ }^{18} \mathrm{~F}-\mathrm{FDG}$ produced in a TRACERlab MX synthesizer, without changing the cassette and reagent composition.

\section{ACKNOWLEDGMENT}

No potential conflict of interest relevant to this article was reported.

\section{REFERENCES}

1. Fawdry RM. Radiolysis of 2-[ ${ }^{18}$ F]fluoro-2-deoxy-D-glucose(FDG) and the role of reductant stabilisers. Appl Radiat Isot. 2007;65:1193-1201.

2. Karwath P, Sartor J, Gries W, et al. Steam sterilization and automatic dispensing of $\left[{ }^{18} \mathrm{~F}\right]$ fludeoxyglucose (FDG) for injection. Appl Radiat Isot. 2005;62:577-586.

3. O'Neil MJ, Heckelman PE, Koch CB, Roman KJ, eds. The Merck Index: An Encyclopedia of Chemicals, Drugs, and Biologicals. 14th ed. Whitehouse Station, NJ: Merck and Co., Inc.; 2006:389.

4. Sweetman SC. Martindale: The Complete Drug Reference. 34th ed. London, U.K.: Pharmaceutical Press; 2004:1075.

5. Rowe RC, Sheskey PJ, Owen SC. Handbook of Pharmaceutical Excipients. 5th ed. London, U.K.: Pharmaceutical Press; 2006:185-187.

6. Wagner R. Deterioration of F-18-FDG product quality caused by heat sterilization in closed product vial? J Labelled Comp Radiopharm. 2003;46(suppl):S1-S403.

7. Búriová E, Macášek F, Melichar F, Kropáček M, Procházka L. Autoradiolysis of the 2-deoxy-2-[F-18]fluoro-D-glucose radiopharmaceutical. J Radioanal Nucl Chem. 2005;264(3):595-602.

8. Jacobson MS, Dankwart HR, Mahoney DW. Radiolysis of 2-[ $\left.{ }^{19} \mathrm{~F}\right]$ fluoro-2-deoxyD-glucose $\left(\left[{ }^{18} \mathrm{~F}\right] \mathrm{FDG}\right)$ and the role of ethanol and radioactive concentration. Appl Radiat Isot. 2009;67:990-995. 